\title{
Assessing Indonesian students' competence in translating French texts of different types
}

\author{
Riswanda Setiadi \\ French Education Department, Faculty of Language and Literature Education, Universitas Pendidikan Indonesia, \\ Bandung, West Java, Indonesia
}

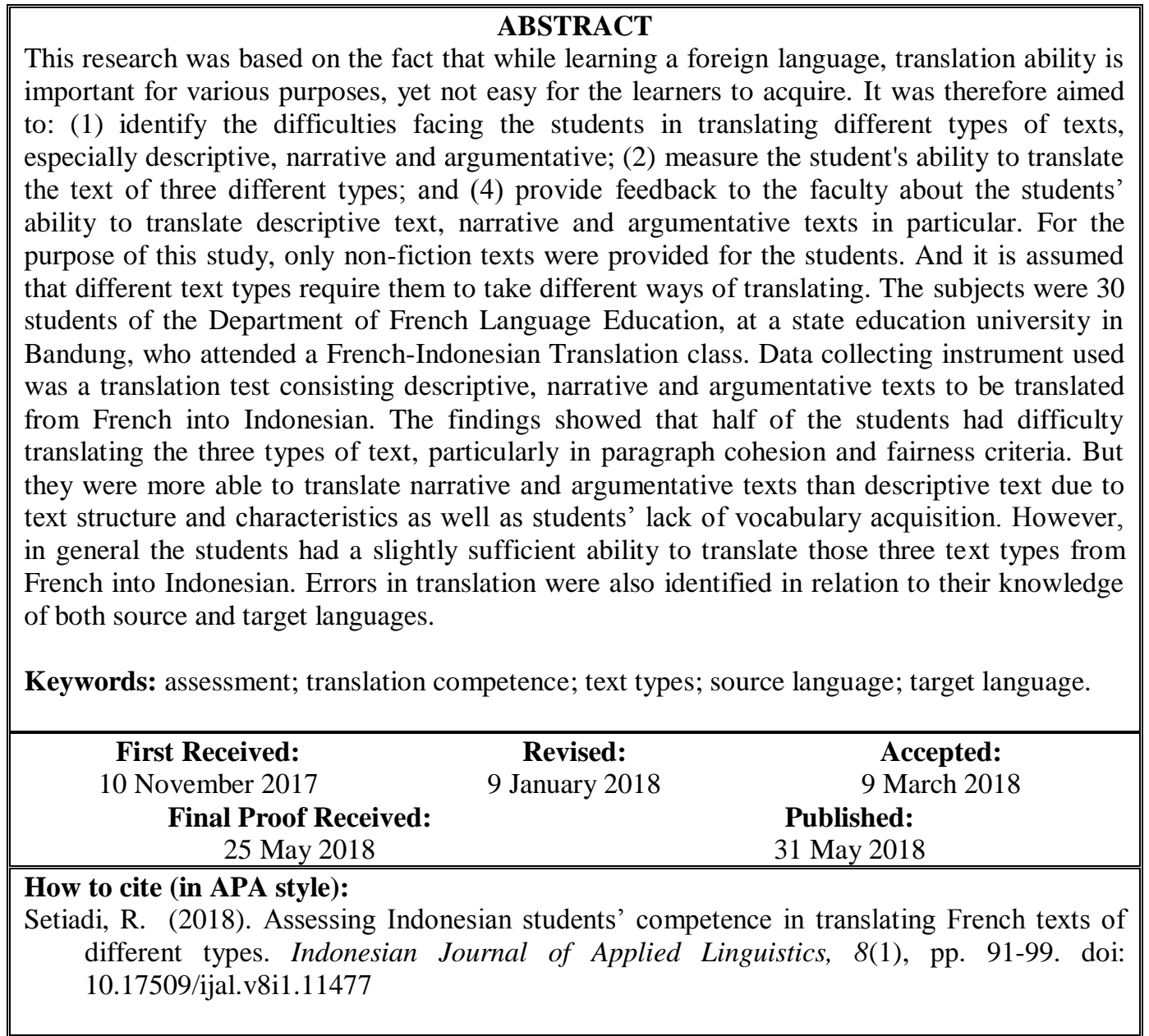

\section{INTRODUCTION}

In general, learning a foreign language is to make learners to be able to communicate with native speakers for various purposes. In this learning process, translation is most likely involved. As we are aware, translation serves different functions, religious, cultural, academic, professional, and the like. It is an important language skill that foreign language learners should master. Hence, they seemingly cannot avoid the learning process of translation because it naturally takes place in learning any foreign language. It is true, however, that translation is not only related to the ability to understand words translated from a source language to the target language. In fact, it is a language skill closely related to other prerequisite language skills, mostly reading comprehension and writing skills.

In many foreign language institutions in the world, translation courses are offered to the students for a variety of purposes. Due to the important roles played by the translation skill, some well-known translation training and certification agencies have been founded, such as Ecole Supérieur de Interprète et de Traducteur 
(ESIT) in Sorbonne University Paris, American Translator Association (ATA) in USA, Australian Training Institute (ATI) in Australia, and the like. The translation training in those institutions is provided for students as well as professionals. In the case of French language translation, non-francophone speakers need it for various purposes and work on a large array of texts. It is even an important part of French language curriculum in many universities in the world. In the case of Indonesia, for instance, French-Indonesian translation skills are taught mostly at university level to allow the students to able to translate various documents or manuscripts for different purposes.

However, translation is not an easy task for language learners due to various reasons. Internal and external linguistic factors are common to make the translation process complex or even complicated. Foreign language learners in particular are supposed to deal with similar linguistic situations as presented by different studies (Karimnia, 2012; Elmgrab, 2013). Therefore, it is not surprising when foreign language teachers should take into account appropriate translation teaching strategies and assessment techniques as Clavijo and Marin (2013) and Elmgrab (2014) suggested in their study.

For the sake of the current study, this manuscript discusses theories closely related to translation process, text types, and translation assessment to strengthen conceptual ideas and address the research issues.

\section{The nature of translation}

The process of translation consists in conveying the message and meaning from of the source text into the target text. To better understand the process of translation, a translation student or lecturer needs to consider some factors closely related the structural characteristics, the expressive potential and the constraints of the two languages involved in translation, and other linguistic, extra-linguistic, and metalinguistic issues (Houbert, 2002). Furthermore, "translation is subject to a variety of extra-linguistic factors and conditions and this is what makes translation such a complex phenomenon" (Foley \& Deocampo, 2016: 146). In this case, a translator is required to acquire knowledge, skill, experience, training and education, as well as the relevant cultural background. In some cases, translation is identical to bilingualism (Kolawole, 2012). It can be meant that there is a balanced acquisition of source language and target language, even it is not always the case. Meanwhile, Newmark (1995) argued that good translation is dependent on three important characteristics of a translator: (1) reading comprehension skill in a foreign language; (2) knowledge of the subject or topic of the translation; (3) sensitivity to the language (first and foreign languages); and (4) ability to write in the target language clearly, effectively and efficiently.

In daily practice, translation students in this study apply two general techniques: correspondence and equivalence. The translation by correspondence is conducted on specific words that produce other ideas in a text, while the translation through equivalence takes place when the source language text requires the translator to involve cognitive or affective aspect which results in an interpretation. According to Lederer (1994), translation by correspondence is not uncommon to produce and process the translation product of poor quality because there is no compatibility between the source language and the target language. However, each language has its own characteristics. Linguistic approach with the corresponding techniques can be effective in a particular case or field.

Meanwhile, translation through equivalence requires attention because there are no words or grammatical structures in all the languages that are really correspondent. This probably reminds us of lexical gaps, especially in French and Indonesian. Furthermore, Lederer (1994) asked: " Qu'est-ce qui permet de dire qu'une traduction est à l'original équivalente, alors que les mots ni les structures grammaticales correspondent exactement pas?' In this case, translation cannot be an original equivalence in terms of lexical and grammatical structures. Subsequently, citing the opinion of Werner Koller, Lederer (1994) delivered five criteria for determining equivalence of a translation, namely (1) the translation must convey the information about extra-linguistic reality in the source text; (2) the translation must respect the style: language varieties, sociolect, regional identity, expression, and others; (3) the translator must pay attention to the type (genre) of the translated text; (4) the translation must be adjusted to the readers' knowledge to make it easy to understand; and (5) the translation must have an aesthetic impact like the original text. Based on the five categories above, there are five criteria for assessing the equivalence of the translation results, namely (1) denotative equivalence; (2) connotative equivalence; (3) normative equivalence; (4) pragmatic equivalence; and (5) aesthetic equivalence.

In particular, equivalence in translation is packed with a variety of interpretative acts. In the case of French into Indonesian translation, students have to consider the equivalence when correspondence is barely possible because in many cases, Indonesian words cannot correspond to French ones or vice versa. However, both correspondence and equivalence were not deeply considered in this study as it mainly focuses on elaborating the students' ability to translate the different text types.

Furthermore, like reading and writing, translation activity cannot be separated from text types because they constitute an important element that should be learned to uncover the author's ideas and thoughts in different ways. After all it is closely related to the process of reading and writing. It means that translation can be understood as a process of finding and reexpressing a message or meaning in the source language into the target language. In particular, Chung-lin (2007) suggested that teaching text types in translation cannot 
be neglected for the sake of communicative teaching. Considering the text types, Newmark (1995) classified text into three categories: (1) scientific-technological; (2) institutional-cultural; and (3) literary. These three categories of text may be differentiated according to the context or contents. In the context of this study, however, the text types are distinguished by its structure: descriptive, narrative, and argumentative. Regarding their structure, those three text types bring translators different levels of difficulty.

\section{Assessment of translation skills}

Basically, translation is taught for academic and professional purposes. University translation teaching is mostly intended to develop students' translation skills for academic purposes and tasks. A crucial issue dealing with translation teaching for these purposes is assessment. As teaching different types of text in translation is always demanding and delicate, the assessment is always so due to the different characteristics of text types. Horguelin (n.d. in Melis \& Albir, 2001) argued that translation assessment has long been a very subjective work, and that only recently signs of a more methodical approach have appeared. Today, the assessment of translation quality has accentuated the search for more objective systems of evaluation, ranging from simple value scales to sophisticated global models. That is why Koskinen (2016) contended that a multidisciplinary approach is needed to scrutinize the translation.

The issue on translation assessment leads to the question of what competence(s) should be assessed in the teaching context. Ressurrecció, Piorno, and Izquierdo (2008) argued that the practice of translation and teaching translation require a single competence that is made up of or could be considered to integrate a set of competencies that include, for instance, competence in both the source and the target languages. Furthemore, Neubert (2000) elaborated the requirements for a translator to meet: (1) it is necessary to take into account a series of contextual factors underlying the knowledge and skills required of translators, namely: the complexity, the heterogeneity, and the approximate nature of the expert knowledge possessed by translators; (2) having the capacity to get an idea of the subject matter and facilitate understanding between experts belonging to different cultures and in different languages; (3) being aware of the situationality of translation and to be capable of adapting themselves to both recurring and novel situations; and (4) being able of dealing with the changing situations arising from the very historicity of their work.

There are of course other requirements a translator should meet. For instance, a good translation practice requires that the translator has good mastery of both the source and target languages. The mastery is not limited to linguistic knowledge of the source and target languages but also to the cultural knowledge embedded in the two languages. In this case, Madkour (2016, p. 94) suggested that "translation requires different knowledge in syntactic, semantic, cultural, stylistic and lexical areas". In terms of translation product, a target text translated from a source text should be acceptable to the readers (Castillo, 2015). In this case, the translator is required to translate a text as if s/he wrote it on her/his own. The readers should feel that they read an original work, rather than translated work. Hence, acceptability is a crucial requirement of a good translation practice.

In assessment practices, the translation products are always typical in terms of different translator's styles or competences which are visually recognized in textual features. Al-Qinai (2000) proposed that translation assessment mainly focused on textual typology, formal correspondence, coherence of thematic structure, cohesion, text-pragmatic equivalence, lexical properties, and grammatical/syntactic equivalence. Meanwhile, Brown (2007) took into account clarity, cohesion, accuracy and fairness of translation products as main indicators of the translation assessment. Of course, those parameters are not easy to be applied in the translation assessment practice. According to Eyckmans, Anckaert and Segers (2013), to make indicators more consistent and reliable, we need to construct assessment grids based on a criterionreferenced approach. For the sake of the current study, Hence, Brown's indicators were further elaborated into a $1-5$ scale rubric of assessment as presented below.

\section{METHOD}

The research was carried out in a Department of French Language Education at a teacher education institution in Indonesia, and it applied a descriptive method to describe the current circumstance of student translation ability and involved 30 students who attended a FrenchIndonesian Translation course, an intermediate course currently offered as an elective subject at the university. They participated in this study for 3-4 hours per week for three months. During the period of research, students practiced the translation of three text types, but their translation work was not assessed. The practice was intended to familiarize them with the characteristics of each text type and prepare them for the translation test. So, the data were only collected from a translation test consisting of French descriptive, narrative and argumentative texts, and individual texts had approximately 350 words in length. Instead of integrated translation, those three text types were tested separately as the students had been taught about them since early period of their study, mostly in the writing courses. The descriptive text was entitled Mme Bertrand, gardienne d'immeuble, the narrative text title was Farida, une jeune Algérienne en France, and the argumentative text was La Télévision (Barthe \& Chovelon, 2003). Those texts were selected as they contained familiar and allegedly interesting for the students. Each text translated by the students was then treated individually on the basis of Brown's criteria as mentioned above. 
In the data processing, there was no statistical calculation or formula. Data were collected through scoring on every case (the texts translated by the individual students). Scores achieved by each student in each criterion or category indicates the strength or weakness in these criteria. Furthermore, each of the scores achieved were further elaborated in the form of a description that explains the strengths or weaknesses.

As mentioned above, the data collected in this study were obtained from the test results, and the translation assessment was designed on the basis of the criteria of clarity, cohesion, accuracy and fairness (Brown, 2007) as presented below. In this case, those criteria refer to Indonesian language rules as the target language is Indonesian. Other validated criteria are of course available, but Brown's criteria were chosen as they are seemingly simple and likely to be generally applied to different text types. However, as mentioned above, they had to be accurately transformed into an assessment tool.

The first criterion, clarity, is related to the correctness of spelling and punctuation, grammar, choice of words and linguistic style of the translation work done in the target language as presented in Table 1.

Table 1. Clarity criterion to assess students' translation

\begin{tabular}{cl}
\hline Score & \multicolumn{1}{c}{ Clarity criterion } \\
\hline 5 & Text translated into Indonesian is very clear in \\
& terms of grammar, spelling, and punctuations, \\
& as well as word choice as written in French \\
& text.
\end{tabular}

4 Text translated into Indonesian is clear in terms of grammar, spelling, and punctuations, as well as word choice as written in French text.

3 Text translated into Indonesian is fairly clear in terms of grammar, spelling, and punctuations, as well as word choice as written in French text.

2 Text translated into Indonesian is less clear in terms of grammar, spelling, and punctuations, as well as word choice as written in French text.

1 Text translated into Indonesian is unclear in terms of grammar, spelling and punctuations, as well as word choice as written in French text.

Another criterion, cohesion, is to describe the relationship between one sentence and another in order to produce good paragraphs as elaborated in Table 2 . The appropriateness or accuracy criterion is to assess the links or correspondence between the message contained in French text and the message contained in Indonesian text as shown in Table 3.

Finally, Table 4 presents the fairness criterion to examine the use of language by the translator as if it was his own thought without a lot of removal and / or addition of other elements.

Table 2 Cohesion criterion to assess students' translation

\begin{tabular}{cl}
\hline Score & \multicolumn{1}{c}{ Cohesion criterion } \\
\hline 5 & $\begin{array}{l}\text { Sentences are very well connected and result } \\
\text { in good paragraphs. }\end{array}$ \\
4 & $\begin{array}{l}\text { Sentences are well connected and result in } \\
\text { good paragraphs. }\end{array}$ \\
3 & $\begin{array}{l}\text { Sentences are fairly connected and do not } \\
\text { result in good paragraphs. }\end{array}$ \\
2 & $\begin{array}{l}\text { Sentences are poorly connected and do not } \\
\text { result in good paragraphs. }\end{array}$ \\
1 & $\begin{array}{l}\text { Sentences are not connected and do not } \\
\text { result in good paragraphs. }\end{array}$ \\
\hline
\end{tabular}

Table 3. Accuracy criterion to assess students' translation

\begin{tabular}{cl}
\hline Score & \multicolumn{3}{c}{ Accuracy criterion } \\
\hline 5 & $\begin{array}{l}\text { Information in Indonesian text very } \\
\text { accurately represents information in French } \\
\text { text. }\end{array}$
\end{tabular}

4 Information in Indonesian text accurately represents information in French text.

3 Information in Indonesian text fairly describes information in French text.

2 Information in Indonesian text less accurately describes information in French text.

1 Information in Indonesian text does not represent information in French text.

Table 4 Fairness criterion to assess students' translation

\begin{tabular}{cl}
\hline Score & \multicolumn{1}{c}{ Fairness criterion } \\
\hline 5 & $\begin{array}{l}\text { Indonesian text translation is very fair in } \\
\text { terms of language styles. }\end{array}$ \\
4 & $\begin{array}{l}\text { Indonesian text translation is fair in terms of } \\
\text { language styles. }\end{array}$ \\
3 & $\begin{array}{l}\text { Indonesian text translation is sufficiently fair } \\
\text { in terms of language styles. }\end{array}$ \\
2 & $\begin{array}{l}\text { Indonesian text translation is less fair in } \\
\text { terms of language styles. } \\
1\end{array}$ \\
& $\begin{array}{l}\text { Indonesian text translation is not fair in terms } \\
\text { of language styles. }\end{array}$
\end{tabular}

To apply research design mentioned above, the research procedures undertaken are as follows. Firstly, the students were presented with French descriptive, narrative, and argumentative texts and translated those texts into Indonesian. Secondly, individual texts were then analyzed by using those four criteria for the feasibility, structure and logics of the language contained in their translations. Scoring was done on the basis of a $1-5$ range rubric develop from Brown's 
assessment criteria. Finally, translation patterns in any type of texts translated for the sake of this study were identified.

\section{FINDINGS AND DISCUSSION}

In translating the descriptive text, data on the students' ability to translate a French descriptive text into Indonesian are shown in Table 5. It shows that the clarity and accuracy constitute criteria the students cannot fulfil. In this case, the descriptive French text translated into Indonesian resulted in a less clear text in terms of grammar, spelling, punctuations, and word choice on the clarity criterion, but more students constructed the sentences that were fairly connected despite unstructured paragraphs in terms of cohesion. Meanwhile, most students were unable to translate the descriptive text accurately. However, they were generally capable of presenting fair language styles.
In translating the descriptive text, none of the respondents were able to reach a score of 5 with very clear criterion and only one $(3 \%)$ of the respondents were able to reach a score of 4 with clear criterion. While the score 3 is achieved by nine (30\%) respondents with a fairly clear criterion and 20 (67\%) respondents only scored 2 . For the category of cohesion paragraph, $12(41 \%)$ of respondents scored 2 with a less appropriate criterion, $16(53 \%)$ scored 3 , and two people to obtain a score of 4 with the appropriate criterion. But no one respondent managed to obtain the highest score of 5 with a very appropriate criterion. For accuracy criterion, none of the 30 respondents were able to achieve very precise criterion with a score of 5 , but there are two $(6 \%)$ respondents were able to achieve the proper criterion of the score 4 . While five (17\%) respondents achieve sufficient criterion and score 3 , and $20(60 \%)$ of respondents can only achieve less precise criterion with a score of 2 and three $(10 \%)$ of the respondents got the lowest score.

Table 5 Descriptive text translation data

\begin{tabular}{ccrcrrrrr}
\hline & Clarity & \multicolumn{2}{c}{ Cohesion } & Accuracy & \multicolumn{2}{c}{ Fairness } \\
\cline { 2 - 8 } Score & No of students & $\%$ & No of students & $\%$ & No of students & $\%$ & No of students & $\%$ \\
\hline 5 & 1 & 3 & 2 & 6 & 2 & 6 & 5 & 17 \\
4 & 9 & 30 & 16 & 53 & 5 & 17 & 16 & 53 \\
3 & 20 & 67 & 12 & 41 & 23 & 77 & 9 & 30 \\
2 & & & & & & & & \\
1 & & &
\end{tabular}

On the fairness criterion, the scores obtained by the respondents are quite varied with a range of 2 to 4 , no one can reach the score 5. However, nine (30\%) respondents scored 2, $16(53 \%)$ respondents scored 3, and five $(17 \%)$ respondents scored 4 respectively.

The following sentences were well translated into Indonesian and scored 4.

(1a) Les immeubles modernes peuvent avoir jusqu'à quinze ou vingt étages. Ils sont conçus d'une manière plus moderne: ils sont tous équipés d'un ou de plusieurs ascenseurs, de vide-ordures, de grande baies vitrées qui donnent beaucoup plus de lumière et d'air, souvent de balcons. La vie y est différente, mais beaucoup plus anonyme.

(1b) Bangunan modern bisa bertingkat 15 atau 20. Gedung-gedung dirancang dengan lebih modern dan dilengkapi dengan satu atau beberapa lift, tangga, jendela kaca besar yang dapat memberi lebih banyak cahaya dan udara, dan juga balkon. Kehidupan di sini berbeda, tapi banyak orang tak dikenal.

The translation of French narrative text into Indonesian has resulted in the data as shown in Table 6.

Table 6 Narrative text translation data

\begin{tabular}{ccrcrrrrr}
\hline & \multicolumn{2}{c}{ Clarity } & \multicolumn{2}{c}{ Cohesion } & Accuracy & \multicolumn{2}{c}{ Fairness } \\
\cline { 2 - 8 } Score & No of students & $\%$ & No of students & $\%$ & No of students & $\%$ & No of students & $\%$ \\
\hline 5 & 1 & 3 & 2 & 6 & 2 & 6 & 5 & 17 \\
4 & 9 & 27 & 16 & 53 & 5 & 17 & 16 & 53 \\
3 & 20 & 67 & 12 & 41 & 20 & 67 & 9 & 30 \\
2 & & & & & 3 & 10 & & \\
1 & & & & &
\end{tabular}

In the narrative text translation, the data show that the criteria of clarity and accuracy still became a problem for most students. In the criterion of clarity, none of the respondents were able to reach a score of 5 with very clear criterion, and only two (6\%) respondents were able to reach a score of 4 with clear criterion. While the score of 3 is achieved by $18(54 \%)$ respondents with a fairly clear criterion and nine $(30 \%)$ respondents only scored 2 and criterion is less clear. For cohesion paragraph, seven respondents scored 2 with a less appropriate criterion, 19 (57\%) respondents scored three criterion quite fit, and four (12\%) of people received grades 4 with the appropriate criterion. But no one respondent who managed to obtain the highest score of 5 with a very appropriate criterion. Meanwhile, for the accuracy criterion, none of the 30 respondents were able to achieve very precise criterion with the score 5 . However, there were six (20\%) respondents were able 
to achieve precise criterion with a score of 4 . While the $14(42 \%)$ respondents achieve sufficiently precise criterion with a score of 3 , and nine (30\%) of respondents can only achieve less precise criterion with a score of 2 and one (3\%) of the respondents to obtain the lowest score is 1 , the criterion is not appropriate. Finally, the scores of fairness criterion achieved by the students are quite common with a $2-4$ range, but no one can reach the score 5. Five respondents are at fairness criterion with score 2. Nineteen students reached a score of 3 with a fairly reasonable criterion and six were at a reasonable criterion with a score of 4 .

The following is a sentence example which was given the highest score of 4 .

(2a) Le premier jour ils ont marche. Mais les distances étaient trop longues. Le second jour ils ont pris un autobus, mais ils n'ont pas su prendre les bonnes correspondances. Au bout de trois jours finalement ils ont pris le métro.

(2b) Hari pertama mereka berjalan kaki tetapi jaraknya terlalu jauh. Hari kedua mereka naik bis tetapi mereka tidak tahu arah. Pada hari ketiga akhirnya mereka naik metro.

In most cases, the students produced unclear sentences and less cohesive paragraphs. The similar achievement can be found in accuracy and fairness criteria. Only very few students were able to translate French sentences and paragraphs into a clear, accurate and cohesive Indonesian text.

The following data presented in Table 7 describe the students' ability to translate French argumentative text into an Indonesian version.

\begin{tabular}{crrrrrrrr}
\multicolumn{7}{c}{ Table 7 Argumentative text translation data } \\
\hline \multirow{2}{*}{ Score } & Clarity & \multicolumn{2}{c}{ Cohesion } & Accuracy & Fairness \\
\cline { 2 - 9 } & No of students & $\%$ & No of students & $\%$ & No of students & $\%$ & No of students & $\%$ \\
\hline 5 & 1 & 3 & 2 & 6 & 2 & 6 & 5 & 17 \\
4 & 9 & 30 & 16 & 53 & 5 & 17 & 16 & 53 \\
3 & 20 & 67 & 12 & 41 & 20 & 67 & 9 & 30 \\
2 & & & & & 3 & 10 & & \\
1 & & & & & & &
\end{tabular}

The analysis of argumentative text translation shows a different trend. Most students still have difficulties translating French texts into Indonesian accurately in terms of specific terms or words. In the criterion of clarity, Table 7 shows that none of the respondents were able to reach a score of 5 with very clear criterion, and only two (6\%) respondents were able to reach a score of 4 with clear criterion. While the score of 3 is achieved by nine $(30 \%)$ respondents with a fairly clear criterion and 17 (51\%) of respondents only scored two criterion are less clear. For cohesion paragraph, 13 (42\%) respondents scored 2 with a less appropriate criterion, $16(48 \%)$ respondents scored three in this criterion, and one (3\%) respondent scored 4 with the appropriate criterion. But no one respondent managed to obtain the highest score of 5 with a very appropriate criterion. For accuracy criterion, none of the 30 respondents were able to achieve very precise criterion with the score 5 . However, there are two $(6 \%)$ respondents were able to achieve precise criterion with a score of 4 . While nine $(30 \%)$ respondents gained sufficiently precise criterion with a score of 3 , and 19 (63\%) of respondents could only achieve less precise criterion with a score of 2 . In fairness criterion, the scores achieved by the students were quite diverse a range of 2 to 4 , and no one could get score of 5 . However, $13(43 \%)$ respondents were at less fair criterion with score 2 and $12(40 \%)$ respondents reached a score of 3 with a fairly reasonable criterion and two (6\%) respondents have score 4.

The following sentences present an example of good translation made by a student despite some improper word choices. (3a) Grande séductrice des temps modernes, la télévision tient une place très importante dans notre quotidien et s'impose plus que jamais au cœur de nos habitations. Une enquête récente révèle que les enfants de 4 a 14 ans passent en moyenne $2 \mathrm{~h} 18$ par jour devant la télé, temps moins important que celui des adultes qui, eux, le regardent en moyenne $3 \mathrm{~h} 32$ au quotidien.

(3b) Penggoda besar zaman modern, televisi memegang tempat yang sangat penting dalam kehidupan kita sehari-hari dan lebih penting daripada sebelumnya di jantung rumah kita. Sebuah survei baru-baru ini mengungkapkan bahwa anak-anak berusia 4 hingga 14 tahun menghabiskan rata-rata 2 jam 18 per hari di depan TV, lebih sedikit waktu daripada orang dewasa, yang, rata-rata, menonton 3:32 jam setiap hari.

Considering the above described data, it appears that students had a sufficient and satisfactory ability to translate the narrative and argumentative texts. In the clarity criterion of narrative text, $18(54 \%)$ of the respondents obtained a score of 3 . In other words, they were able to translate the narrative text more clearly than descriptive text and/or argumentative text. Furthermore, they were able to produce good paragraph cohesion in translating argumentative text, which amounted to $48 \%$. Based on the whole data, it can be argued that most students did not have adequate ability in other categories in all three types of text. And it can be understood that translating a narrative text was seemingly easier than translating two other types of text as it contains information that is easy to understand and its structure is less complex and complicated than those 
both texts. In particular, the students found the descriptive text more complex to translate so they made more mistakes when translating it. Furthermore, they faced difficulties translating detailed information in translating the descriptive text. In this case, considering Al-Qinai's statement (2000) as mentioned above, the students were familiar with the textual typology, but they were unable to present their best performance in relation to formal correspondence, coherence of thematic structure, cohesion, text-pragmatic equivalence, lexical properties, and grammatical/ syntactic equivalence.

Furthermore, data collected in this study reveal that in addition to familiarity with the characteristics of individual text types, the translation process requires the students to be linguistically balanced. It means that they should master the source and target languages at an equal level in all language components. Data also show that the students were mostly able to fulfil the criteria of cohesion and fairness, while they were weak in the criteria of clarity and accuracy. It is understandable that unlike writing skill, translation skill does not require the students to compose a new text because the source text is already available in the translation process. This is the reason why they did not face difficulty translating any type of text in terms of cohesion and fairness. Meanwhile, clarity and accuracy criteria demand them to interpret the meanings and messages of the source text by selecting appropriate vocabulary, obeying grammatical rules, adopting a proper style and the like. This finding is similar to a previous finding by Chunglin (2007) that proved that most students found it difficult to infer how text types are relevant to the translation process despite their knowledge of and familiarity with them. In this case, they should of course mobilize and make use of their language competences at the highest level.

When we take a closer look at the translation data, a few common errors can be found as presented the table below. Based on the data, types of error are related to the students' inappropriate knowledge of both source and target languages in terms of spelling and word choice as well as lack of vocabulary. This finding is in accordance with Neubert's position (2000) in relation to the criteria of a translator. It seemingly reveals that the students who participated in this study could not take into account a series of contextual factors underlying the knowledge and skills required of translators, namely, the complexity, the heterogeneity, and the approximate nature of the expert knowledge possessed by translators. In addition, they did not have the capacity to get an idea of the subject matter and facilitate understanding between experts belonging to different cultures and in different languages, were not aware of the situationality of translation and to be capable of adapting themselves to both recurring and novel situations, and were unable to face the changing situations arising from the very historicity of their work.

Based on the four assessment criteria, four general types of errors are presented in Table 8: inappropriate word choice, wrong use of punctuations and spelling in the target language, grammatical errors, and wrong correspondence and equivalence. In many cases, those errors are pedagogically valuable and useful when appropriately analyzed. It means that those errors are common in all types of texts translated by the students and correctable. In practice, both lecturers and students can fix them by complying with rules of both source and target languages.

Hence, the complexity of translation process requires complex teaching activity, but the improvement of translation skills is not necessarily complex or complicated. It depends on various variables. It seems that strengthening the basic skills of foreign language becomes an important requisite for the translation students and lecturers to acquire a good quality translation skill. On the other hand, the native status of Indonesian speakers does not guarantee that we can use the native language properly. For the sake of translation learning, improving the acquisition of the native language as the target language should be an important component of the pedagogical processes. Regardless of translation techniques in use, the quality of translation will always be dependent on the assessment process. Brown's assessment criteria was appropriate for the sake of this study, but many more instruments can be applied to assess the translation learning achievement. However, as the translation process involves the translator's competences in two different languages, a fair assessment is more important to evaluate the quality of translation, and of course, a quality translation.

\section{CONCLUSION}

Based on the research findings, some conclusions can be drawn. Firstly, the students' ability to translate French descriptive text into Indonesia is only less and fairly effective. Secondly, their ability to translate French text narrative into Indonesian was still quite good with a number of weaknesses in some of the criteria, particularly paragraphs cohesion and fairness as described above. Thirdly, students' ability to translate French argumentative text into Indonesian was also at fairly good level. In this type of text, students have the fairly good ability in the category of paragraphs cohesion. Fourthly, based on the results of three translation tests, it can be noted, however, that the students' translation competence was slightly low. This is evident from the many errors made by students in the effective use of capital letters, punctuations, word choices and sentence structures in those three text types. This is supported by the observation of the majority of students who faced the difficulties to express message from French into Indonesian language properly, so they tended to use the non-standard Indonesian.

The students are recommended to recognize the characteristics of individual text types to be able to translate them well. It is true that the vocabulary and text comprehension is very important in the translation process, but the transmission of the text characteristics 
is not less important. In some respects, the students are also encouraged to develop their skills in using appropriate translation techniques properly in order to make effective translator. In addition, the lecturers who manage translation course are also advised to enrich the learning process with various text types so that students have rich learning experiences and focus on the current weaknesses of the students' translation skill.

Table 8 General types of error

\begin{tabular}{|c|c|c|}
\hline No & Types of error & Note \\
\hline 1. & $\begin{array}{l}\text { Inappropriate word choice, such as the use of word "kita" (it should be "we" as it refers to } \\
\text { French word); "kamu" (it refers to "vous" used to respect older people); and "dia" (deriving } \\
\text { from "ill" acting as a French male personal referring to word "appartement" in the text). } \\
\text { Example: Il a au moins trois pièces, en plus de } \\
\text { la salle de bains et de la cuisine. } \\
\text { (Dia punya tiga bagian, ditambah } \\
\text { kamar mandi dan dapur.) }\end{array}$ & $\begin{array}{l}\text { This error is closely } \\
\text { related to word choice and } \\
\text { inappropriate knowledge } \\
\text { of source language. }\end{array}$ \\
\hline 2. & $\begin{array}{l}\text { The use of punctuations and spelling in Indonesian. } \\
\text { Example: La télévision nous permet d'oublier } \\
\text { pour un temps nos soucis. } \\
\text { (televisi membuat kita lupa masalah } \\
\text { kita untuk sementara) }\end{array}$ & $\begin{array}{l}\text { This error is allegedly } \\
\text { caused by lack of target } \\
\text { language knowledge. }\end{array}$ \\
\hline 3. & $\begin{array}{l}\text { Inappropriate use of certain words or grammatical elements such as prepositions in } \\
\text { Indonesian. } \\
\text { Example: Grande séductrice des temps modernes, la } \\
\text { télévision tient une place très importante } \\
\text { dans notre quotidien et s'impose plus que } \\
\text { jamais au cœur de nos habitations. } \\
\text { (Penggoda besar zaman modern, televisi } \\
\text { memegang tempat yang sangat penting } \\
\text { dalam kehidupan kita sehari-hari dan lebih } \\
\text { penting daripada sebelumnya dijantung } \\
\text { rumah kita.) }\end{array}$ & $\begin{array}{l}\text { The error is also related to } \\
\text { the poor knowledge of } \\
\text { Indonesian language } \\
\text { spelling system. }\end{array}$ \\
\hline 4. & $\begin{array}{l}\text { Inappropriate correspondence and/or equivalence, such as "vide-ordures" (trash bin) } \\
\text { translated into "trash cleaner, "parasite trash" or "vacum cleaner", "immeuble" (apartment } \\
\text { building) translated into flats. }\end{array}$ & $\begin{array}{l}\text { This error is due to poor } \\
\text { knowledge and acquisition } \\
\text { of source language } \\
\text { vocabulary. }\end{array}$ \\
\hline
\end{tabular}

\section{REFERENCES}

Al-Qinai, J. (2000). Translation quality assessment: Strategies, parametres, and procedures. Meta : journal des traducteurs/Meta: Translators' Journal, 12(2), 497-519. doi 10.7202/001878ar.

Barthe, M. \& Chovelon, B. (2003). Le français par les textes II : 45 textes de français courant. Grenoble, France : Presses Universitaires de Grenoble.

Brown, H.D. (2007). Teaching by principles: An interactive approach to language pedagogy (3rd Ed). New York: Pearson Longman.

Castillo, L.M. (2015). Acquisition of translation competence and translation acceptability: An experimental study. The International Journal for Translating and Interpreting Research, 7(1), 7285.

Chung-lin, S. (2007). Teaching Translation of Text Types with MT Error Analysis and Post-MT Editing. Translation Journal, 11(2). Retrieved from: http://translationjournal.net/journal/40edu.htm

Clavijo, B. \& Marin, P. (2013). Identifying translation teaching strategies: An exploratory study.
International Journal of Humanities and Social Science, 3(21), 71-78.

Elmgrab, R. A. (2013).Implication for translation teaching pedagogy. A case of Benghazi University. Procedia - Social and Behavioral Sciences, 70, $358-369$.

Elmgrab, R. A. (2016). Possible Criteria for Evaluating Students' Translation Errors. International Journal of Humanities and Cultural Studies, 1(3), 131-145.

Eyckmans, J., Anckaert, P., \& Segers, W. (2013, January). Assessing translation competence. In Actualizaciones en communicación social (Vol. 2, pp. 513-515). Ediciones Centro de Linguistica Applicada.

Foley, J.A. \& Deocampo, M.F. (2016). The use of English as a lingua franca in translation. Indonesian Journal of Applied Linguistics, 5(2), 146-153.

Houbert, F. (2002). Saisir les subtilités qui existent entre l'anglais et le français? Translation Journal, 6(3), 1-6.

Karimnia, A. (2013). Undergraduate translation training: In search of a model. Social and Behavioral Sciences, 70, 915-921. 
Kolawole, S.O. (2012). Is every bilingual a translator? Translation Journal, 6(2), 1-9.

Koskinen, K. (2016). Translation: A Multidisciplinary Approach. Translation Studies, 9(2), 233-236. doi: 10.1080/14781700.2015.1064322.

Lederer, M. (1994). La traduction aujourd'hui. Paris : Hachette FLE.

Melis, N.M. \& Albir, A.H. (2001). Assessment in Translation Studies: Research Needs. Meta: journal des traducteurs / Meta: Translators' Journal, 46(2), 272-287.
Newmark, P. (1995). A textbook of translation. New York: Prentice-Hall.

Neubert, A. (2000). Competence in language, in languages, and in translation. Amsterdam and Philadelphia: John Benjamins.

Ressurrecció, V.M., Piorno, P.E. \& Izquierdo, I.G. (2008). The acquisition of translation competence through textual genre. Translation Journal, 12(4), 43-48. 